\title{
Peningkatan Ketelitian dan Keterampilan Menulis Bahasa Indonesia dengan Model Pembelajaran PBL Secara Daring Siswa Kelas V SDN Cangkringan 1
}

\author{
Fadila Priyanasari $^{* 1}$, Andri Anugrahana ${ }^{2}$, Ehsan Zaini ${ }^{3}$ \\ ${ }^{1,2,3}$ Program Pendidikan Profesi Guru Sekolah Dasar, Universitas Sanata Dharma Yogyakarta \\ Email: ${ }^{1}$ fadila11feb97@gmail.com, ${ }^{2}$ andrianugrahana@gmail.com, ${ }^{3}$ ihsanzaini@ gmail.com
}

\begin{abstract}
Abstrak
Penelitian ini bertujuan untuk mengetahui peningkatan ketelitian dan keterampilan menulis siswa kelas V SDN Cangkringan 1 dalam pembelajaran bahasa indonesia materi teks eksplanasi melalui model pembelajaran Problem Based Learning (PBL) secara daring. Subjek dalam penelitian ini adalah siswa kelas V SDN Cangkringan 1 pada semester 1 tahun pelajaran 2020/2021. Kelas tersebut berjumlah 9 siswa yaitu 4 siswa lakilaki dan 5 siswa perempuan. Instrumen yang digunakan dalam penelitian ini adalah pedoman wawancara dan lembar observasi. Penelitian ini merupakan Penelitian Tindakan Kelas (PTK) yang dilaksanakan dalam dua siklus. Tiap siklus meliputi 4 tahap yaitu perencanaan, pelaksanaan tindakan, observasi, dan refleksi. Hasil penelitian ini menunjukkan bahwa penerapan model pembelajaran Problem Based Learning (PBL) secara daring dapat meningkatkan ketelitian dan keterampilan menulis siswa kelas V SDN Cangkringan 1 dalam pembelajaran bahasa indonesia materi teks eksplanasi. Peningkatan ketelitian siswa dari kondisi awal rata-rata nilai 41,1 dengan kategori kurang teliti menjadi 75,5 dengan kategori teliti. Peningkatan terjadi juga pada variabel keterampilan menulis dari kondisi awal rata-rata nilai 59, meningkat menjadi 76,5. Sedangkan proses pembelajaran dengan menerapkan model pembelajaran Problem Based Learning (PBL) secara daring dilakukan melalui langkah berikut: 1) Orientasi peserta didik pada masalah, 2) Mengorganisasi peserta didik untuk belajar, 3) Memandu penyelidikan secara mandiri atau kelompok, 4) Mengembangkan dan menyajikan hasil kerja, 5) Menganalisis dan mengevaluasi proses pemecahan masalah. Pembelajaran dilaksanakan dengan memanfaatkan aplikasi google meet dan whatsapp.
\end{abstract}

Kata kunci: ketelitian, keterampilan menulis, model pembelajaran $P B L$

\section{An Increase Precision And Writing Skills In Bahasa Indonesia With Online Learning Model PBL Grade 5 Student Of Cangkringan 1 Elementary School}

\begin{abstract}
This research aims to understand on how to increase precision and the writing skills in Bahasa Indonesia, of the grade 5 students of Cangkringan 1 Elementary School learning this process through the online based learning model Problem Based Learning (PBL). The subjects of this research are students of Cangkringan 1 Elementary School in their first semester of 2020/2021. There are 9 students in total of the class, consisting of 4 males and 5 female students. The instruments that were used for this research are interview guidelines and observation sheet. This research is conducted in a class action research held into two cycles. Each cycle covers 4 different stages, these are: planning, implementing of action, observation, and reflection. The result indicates that implementing of Online 'Problem Based Learning' / PBL increase the accuracy and writing skills of the students in text of explanation of Bahasa Indonesia matter. The result if this research indicates that the implementation of the online Problem Based Learning (PBL) increases the precision and writing skills of the students in text of explanation of Bahasa Indonesia. An increase number of precision has improved from the average of 41.1 to 75.5 . An increase number of enhanced writing skills also occurred from the average of 59.0 to 76.5. The following steps are followed in the application of the learning of Problem Based Learning (PBL): 1) Orientation for students, 2) Organized the students to learn, 3) Guide the research individually or by a group, 4) Develop and present the work result, 5) Analyze and evaluate the process of problem solving. This learning method is easily done through the web application of Google Meet and Whatsapp.
\end{abstract}

Keywords: learning model PBL, precision, skill writing 


\section{PENDAhUluan}

Berdasarkan Permendiknas No 22 tahun 2006 bahasa memiliki peran utama dalam perkembangan intelektual, sosial, maupun emosional peserta didik dan sebagai penunjang keberhasilan dalam mempelajari semua bidang studi. Pembelajaran Bahasa Indonesia diarahkan untuk meningkatkan kemampuan peserta didik untuk berkomunikasi dalam Bahasa Indonesia dengan baik dan benar, baik secara lisan maupun tulis.

Bahasa indonesia menjadi salah satu kurikulum yang penting di ajarkan di sekolah dasar, karena Bahasa Indonesia merupakan bahasa pengantar pada setiap pelajaran yang akan disampaikan. Menurut [1] mengungkapkan bahwa di dalam bahasa, ada empat aspek keterampilan bahasa yaitu keterampilan menyimak, keterampilan berbicara, keterampilan membaca, dan keterampilan menulis. Keempat keterampilan berbahasa tersebut mempunyai keterkaitan. Keterampilan berbahasa biasa disebut juga keterampilan berkomunikasi, karena bahasa merupakan alat untuk berkomunikasi. Di masyarakat, dikenal dua macam cara berkomunikasi, yaitu komunikasi langsung dan komunikasi tidak langsung. Komunikasi dengan cara langsung yaitu seperti menyimak dan berbicara. Sedangkan, komunikasi tidak langsung seperti membaca dan menulis. Menulis berarti mengungkapkan buah pikiran, perasaan, pengalaman, dan hal lain melalui tulisan [2]. Menulis adalah salah satu bentuk berpikir, yang juga merupakan alat untuk membantu orang lain (pembaca) berpikir [3]. Menulis merupakan sebuah keterampilan berbahasa merupakan kemampuan seseorang di dalam mengemukakan sebuah gagasan, perasaan, dan juga pemikiran-pemikiran yang dimiliki kepada orang ataupun pihak lainnya dengan menggunakan sebuah media tulisan [4]. Berdasarkan pernyataan di atas maka menulis sangat diperlukan untuk membangun keterampilan siswa dalam berkomunikasi dan mengeluarkan pendapat. Pentingnya keterampilan menulis di sekolah menuntut siswa untuk dapat membuat sebuah tulisan, salah satu jenis tulisan yaitu eksplanasi. Teks eksplanasi merupakan teks yang berisi penjelasan tentang proses terjadinya fenomena alam, sosial, ilmu pengetahuan dan budaya [5]. Menulis eksplanasi diajarkan kepada siswa agar dapat menjelaskan tentang suatu proses terjadinya fenomena alam, sosial, ilmu pengetahuan dan budaya yang ada disekitarnya. Dalam meningkatkan keterampilan menulis dibutuhkan adanya ketelitian dalam kegiatan menulis. Berdasarkan Kamus Besar Bahasa Indonesia teliti diartikan dengan cermat, seksama, dan berhati-hati di setiap perbuatan yang dilakukan. Dimana teliti adalah sikap manusia yang cermat dan hati-hati dalam melakukan suatu kegiatan belajar maupun aktivitas lainnya.

Berdasarkan hasil wawancara guru kelas dan observasi kepada siswa kelas V SDN Cangkringan 1 yang dilakukan oleh peneliti pada tanggal 14 November 2020, peneliti menemukan permasalahan dari hasil wawancara dan observasi terhadap pembelajaran di kelas V SDN Cangkringan 1. Peneliti memiliki dugaan rendahnya ketelitian dan keterampilan menulis. Selama proses pembelajaran bahasa Indonesia berlangsung guru hanya menggunakan metode tanya jawab, ceramah, dan diskusi tetapi lebih sering menggunakan metode ceramah, guru sangat jarang menggunakan model pembelajaran inovatif. Berikut merupakan hasil observasi awal:

\begin{tabular}{ccc}
\multicolumn{3}{c}{ Tabel 1. Hasil Observasi Awal } \\
\hline Variabel & Hasil observasi & Kategori \\
\hline Ketelitian & 41,1 & Kurang teliti \\
Keterampilan menulis & 59 & Tidak tuntas \\
\hline
\end{tabular}

Melihat hal ini perlu mencari solusi dalam mengatasi masalah tersebut oleh sebab itu peneliti ingin melakukan upaya peningkatan ketelitian dan keterampilan menulis bahasa indonesia pada siswa kelas V SDN Cangkringan 1 menggunakan model Problem Based Learning (PBL) melalui pembelajaran daring. PBL melibatkan siswa untuk memecahkan masalah melalui tahap-tahap atau metode ilmiah [6]. Problem Based Learning (PBL) merupakan sebuah model pembelajaran yang menyajikan berbagai permasalahan nyata dalam kehidupan sehari-hari siswa sehingga merangsang siswa untuk belajar [7]. Dalam model pembelajaran Problem Based Learning (PBL) terdapat 5 langkah yaitu: 1) Orientasi peserta didik pada masalah, 2) Mengorganisasi peserta didik untuk belajar, 3) Memandu penyelidikan secara mandiri atau kelompok, 4) Mengembangkan dan menyajikan hasil kerja, 5) Menganalisis dan mengevaluasi proses pemecahan masalah [8]. Secara umum tujuan pembelajaran Problem Based Learning (PBL) adalah membantu siswa mengembangkan kemampuan berpikir, pemecahan masalah, serta kemampuan intelektual, dan belajar melalui keterlibatan siswa dalam pengalaman [9]. Berdasarkan penjelasan tersebut peneliti tertarik untuk menggunakan model pembelajaran Problem Based Learning (PBL) karena model pembelajaran ini menarik dan dengan langkah-langkah tersebut siswa dibimbing untuk menganalisis masalah, mencari informasi yang tepat, menganalisis pendapat, mengolah data, membuat kesimpulan sehingga dapat menentukan hasil pemecahan masalah dan mengembangkan rasa ingin tahu sehingga pada saat mengembangkan dan menyajikan hasil kerja, siswa dapat meningkatkan ketelitian serta keterampilan menulisnya. Sedangkan pembelajaran dilakukan secara daring karena adanya virus Covid-19. Di akhir tahun 2019 kasus terinveksi virus terjadi di negara Cina yaitu kota Wuhan kemudian menyebar keseluruh dunia 
termasuk Indonesia. Salah satu cara untuk mencegah penyebaran Covid-19 adalah tidak melakukan interaksi secara langsung dan menjaga jarak satu sama lain. Dalam rangka melaksanakan pencegahan ini, berdasarkan Surat Edaran Menteri Pendidikan dan Kebudayaan Nomor 3 Tahun 2020 tentang Pencegahan Corona Virus Disease (Covid-19) pada Satuan Pendidikan dan Surat Edaran Nomor 4 Tahun 2020 tentang Pelaksanaan Kebijakan Pendidikan Dalam Masa Darurat Penyebaran Coronavirus Disease (Covid-19) dimana pembelajaran dilaksanakan secara daring/ jarak jauh, maka siswa belajar dirumah hingga waktu yang belum dapat ditentukan. Siswa belajar dirumah dengan diawasi orang tua dan dipandu oleh guru mata pelajaran secara daring. Oleh karena itu, peneliti tertarik untuk mengadakan penelitian dengan judul "Peningkatan Ketelitian dan Keterampilan Menulis Bahasa Indonesia dengan Model Pembelajaran PBL secara Daring Siswa Kelas V SDN Cangkringan 1”.

\section{METODE PENELITIAN}

Jenis penelitian ini adalah Penelitian Tindakan Kelas(PTK). Penelitian Tindakan Kelas (PTK) merupakan paparan gabungan definisi dari tiga kata penelitian, tindakan, dan kelas, penelitian adalah kegiatan mencermati suatu objek, menggunakan aturan metodologi tertentu untuk memperoleh data atau informasi yang bermanfaat bagi peneliti atau orang-orang yang berkepentingan dalam rangka peningkatan kualitas diberbagai bidang [10]. Penelitian tindakan kelas (Classroom Action Reaserch) merupakan penelitian yang bersifat praktis dan bertujuan untuk memperbaiki kekurangan-kekurangan dalam pembelajaran di kelas dengan cara melakukan tindakantindakan dalam upaya perbaikan kinerja [11]. Desain penelitian dalam penelitian ini adalah desain PTK model Kurt Lewin Penelitian ini menggunakan langkah 2 siklus yaitu siklus I dan II menurut konsep penelitian tindakan Model Kurt Lewin dilakukan empat kegiatan pokok, yakni perencanaan PTK, tindakan, observasi, dan refleksi [12].

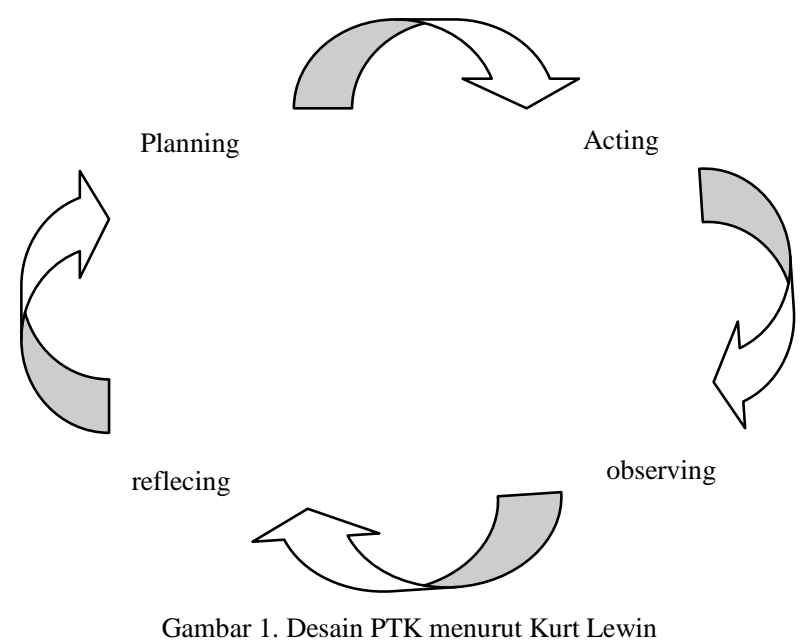

Subjek penelitian adalah siswa kelas V SDN Cangkringan 1 pada semester 1 tahun pelajaran 2020/2021. Kelas tersebut berjumlah 9 siswa terdiri dari 4 siswa laki-laki dan 5 siswa perempuan. Teknik pengumpulan data dalam penelitian ini yaitu dengan wawancara dan observasi. Wawancara dilakukan menggunakan wawancara terstruktur. Wawancara terstruktur adalah wawancara yang dilakukan oleh peneliti yang telah mengetahui dengan pasti tentang informasi apa yang akan diperoleh [13]. Wawancara dilakukan oleh peneliti kepada guru kelas $\mathrm{V}$ untuk memperoleh informasi dari guru mengenai ketelitian dan keterampilan menulis pada siswa kelas $\mathrm{V}$ SDN Cangkringan 1 serta proses pembelajaran yang dilakukan oleh guru. Observasi dalam penelitian ini menggunakan observasi terstruktur. Observasi yang dilakukan oleh peneliti kepada siswa kelas V SDN Cangkringan 1 bertujuan untuk mengetahui ketelitian dan keterampilan siswa dalam menulis.

Instrumen penelitian yang digunakan dalam penelitian ini yaitu pedoman wawancara dan lembar observasi. Adapun instrumen yang digunakan adalah 1) pedoman wawancara. pedoman wawancara digunakan untuk mengetahui data awal mengenai informasi permasalahan dan proses pembelajaran di kelas. 2) lembar observasi. Lembar observasi yang digunakan oleh peneliti digunakan untuk mengetahui ketelitian dan keterampilan menulis siswa sebelum dan setelah dilakukannya tindakan. Lembar observasi disusun berdasarkan dengan indikator yang telah ditentukan oleh peneliti.

Teknik analisis data dalam penelitian ini yaitu menggunakan teknik analisis data kualitatif deskriptif. Berikut peneliti paparkan teknik analisi data dalam penelitian ini. 
Rumus untuk menghitung jumlah nilai ketelitian siswa sebagai berikut.

$$
\text { Nilai ketelitian siswa }=\frac{\text { jumlah skor } \text { ketelitian tiap siswa }}{\text { jumlah skor maksimal }} \times 100
$$

Rumus untuk menghitung nilai rata-rata ketelitian siswa sebagai berikut.

$$
\text { Nilai rata-rata ketelitian siswa }=\frac{\text { jumlah skor ketelitian seluruh siswa }}{\text { jumlah total siswa }} \times 100
$$

Kategori ketelitian siswa dapat diketahui dengan berpedoman pada kriteria ketelitian. Kriteria tersebut dapat dilihat pada tabel berikut [13].

\begin{tabular}{cc}
\multicolumn{2}{c}{ Tabel 2. Kriteria Ketelitian } \\
\hline Interval Skor & Kriteria \\
\hline 80,34 & Sangat Teliti \\
$60,78-80,34$ & Teliti \\
$41,22-60,78$ & Cukup Teliti \\
$21,66-41,22$ & Kurang \\
$\leq 21,66$ & Sangat Tidak Teliti \\
\hline
\end{tabular}

Rumus untuk menghitung nilai keterampilan menulis siswa sebagai berikut.

$$
\text { Nilai keterampilan menulis siswa }=\frac{\text { jumlah skor } \text { keterampilan menulis tiap siswa }}{\text { jumlah } \text { skor maksimal }} \times 100
$$

Rumus untuk menghitung nilai rata-rata keterampilan menulis siswa sebagai berikut.

$$
\text { Nilai rata-rata keterampilan menulis siswa }=\frac{\text { jumlah skor keterampilan menulis seluruh siswa }}{\text { jumlah total siswa }} \times 100
$$

\section{HASIL DAN PEMBAHASAN}

Pada bagian ini akan di deskripsikan penelitian tentang ketelitian dan keterampilan menulis siswa setelah pelaksanaan pembelajaran bahasa indonesia menggunakan model pembelajaran Problem Based Learning (PBL). Peningkatan ketelitian dan keterampilan menulis siswa dilakukan melalui Penelitian Tindakan Kelas (PTK) yang terdiri dari dua siklus. Siklus I dan siklus II terdiri dari 2 kali pertemuan. Setiap pertemuan terdiri dari 2 kali 35 menit.

\subsection{Hasil Penelitian}

Hasil ketelitian dilakukan pada siklus I dan siklus II dengan dua kali pertemuan. Hasil pengamatan diperoleh dari lembar observasi LKPD siswa. Hasil pengamatan dapat disimpulkan bahwa ketelitian siswa mengalami peningkatan pada setiap siklusnya. Berikut merupakan hasil penelitian dari variabel ketelitian siswa.

Tabel 3. Perbandingan Capaian Ketelitian Siswa

\begin{tabular}{ccccc}
\hline \multirow{2}{*}{ Pra Siklus } & \multicolumn{2}{c}{ Siklus I } & \multicolumn{2}{c}{ Siklus II } \\
\cline { 2 - 5 } & Target & Capaian & Target & Capaian \\
\hline 41,1 & 70 & 65,6 & 75 & 75,5 \\
Kurang teliti & Teliti & Teliti & Teliti & Teliti \\
\hline
\end{tabular}

Capaian ketelitian siswa meningkat dari kondisi awal atau pra siklus sampai pada siklus II. Berdasarkan hasil penelitian, capaian ketelitian siswa telah memenuhi target. Berikut merupakan gambar grafik capaian ketelitian siswa. 


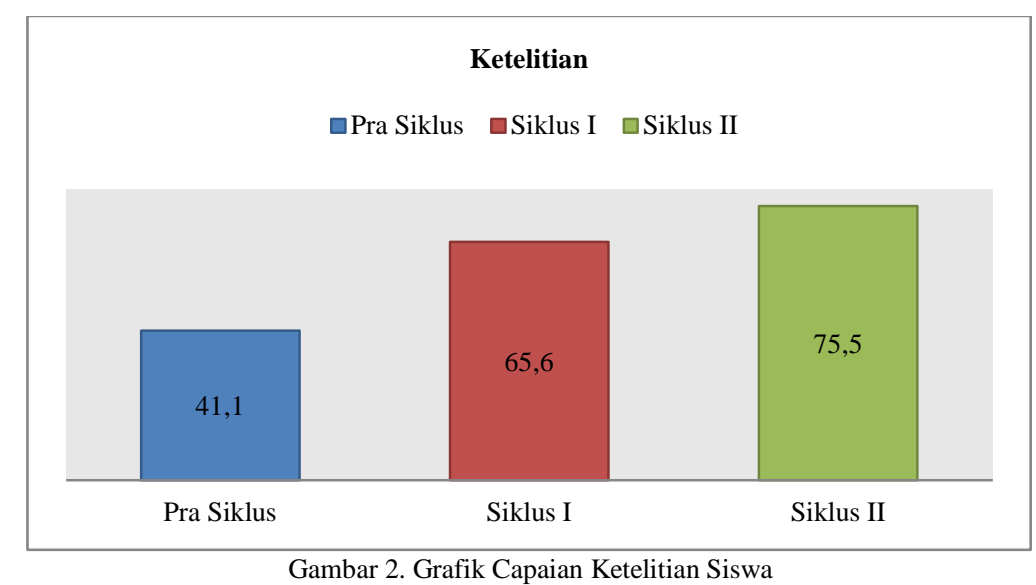

Pada kondisi awal atau pra siklus diperoleh hasil bahwa rata-rata ketelitian siswa yang diperoleh adalah 41,1 dengan kategori kurang teliti. Pada siklus I terjadi peningkatan nilai rata-rata menjadi 65,6 dengan kategori teliti. Kemudian pada siklus II terjadi peningkatan nilai rata-rata menjadi 75,5 dengan kategori teliti. Hasil tersebut senada dengan pendapat [14] teliti merupakan sikap dimana seseorang cermat dalam suatu hal. Teliti mengindarkan seseorang untuk melakukan kesalahan atau hal ceroboh. Teliti berarti pula sebagai sikap waspada atau jeli. Sikap ini memiliki ciri yaitu bersikap waspada yang berarti mawas diri, bersikap berhati-hati yang artinya tenang saat melakukan sesuatu, dan besar perhatian yang artinya mencurahkan segenap perhatian pada sesuatu yang sedang diperbuat. Peneliti menyimpulkan bahwa ketelitian siswa dapat meningkat karena siswa memperhatikan dan jeli dalam melakukan kegiatan menulis teks eksplanasi. Penelitian ini menunjukkan bahwa hipotesis tentang model pembelajaran Problem Based Learning (PBL) dapat meningkatkan ketelitian siswa kelas V SDN Cangkringan 1.

Hasil keterampilan menulis siswa dilakukan pada siklus I dan siklus II dengan dua kali pertemuan. Hasil pengamatan diperoleh dari lembar observasi siswa. Hasil pengamatan dapat disimpulkan bahwa keterampilan menulis siswa mengalami peningkatan pada setiap siklusnya. Berikut merupakan hasil penelitian dari variabel keterampilan menulis siswa.

Tabel 4. Perbandingan Capaian Keterampilan Menulis Siswa

\begin{tabular}{|c|c|c|c|c|}
\hline \multirow{2}{*}{ Pra Siklus } & \multicolumn{2}{|c|}{ Siklus I } & \multicolumn{2}{|c|}{ Siklus II } \\
\hline & Target & Capaian & Target & Capaian \\
\hline 59 & 70 & 67,7 & 75 & 76,5 \\
\hline Belum tuntas & Tuntas & $\begin{array}{l}\text { Belum } \\
\text { tuntas }\end{array}$ & Tuntas & Tuntas \\
\hline
\end{tabular}

Capaian keterampilan menulis siswa meningkat dari kondisi awal sampai pada siklus II. Berdasarkan hasil penelitian, capaian keterampilan menulis siswa telah memenuhi target. Berikut merupakan gambar grafik capaian keterampilan menulis siswa.

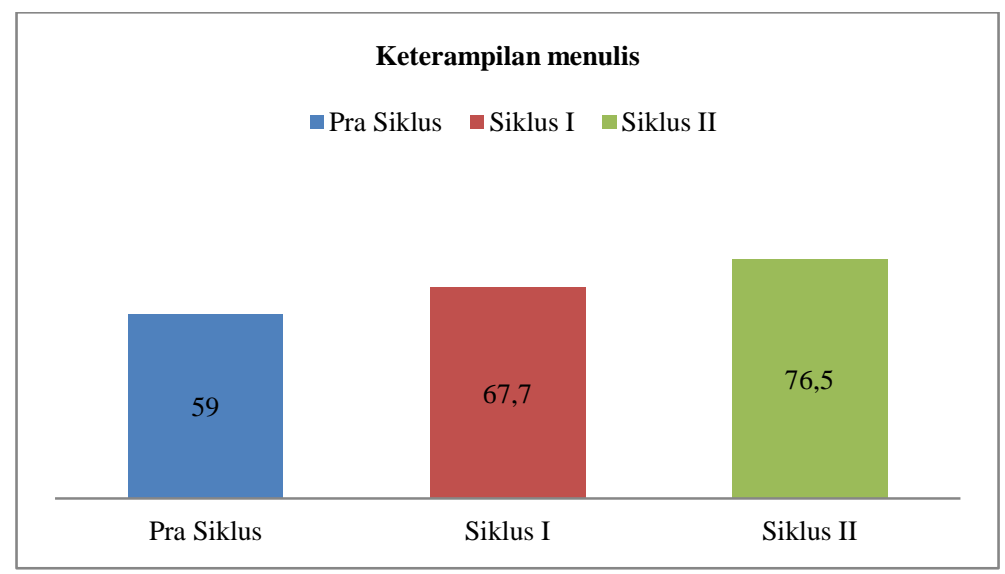

Gambar 3. Grafik Capaian Keterampilan Menulis Siswa 
Pada kondisi awal atau pra siklus diperoleh hasil bahwa rata-rata yang diperoleh siswa adalah 59 dengan kriteria belum tuntas. Pada siklus I mengalami peningkatan menjadi 67,7 dengan kriteria tuntas. Kemudian pada siklus II terjadi peningkatan nilai rata-rata menjadi 76,5 dengan kriteria tuntas.

Berdasarkan hasil peningkatan keterampilan menulis siswa tersebut peneliti simpulkan bahwa peningkatan terjadi karena siswa mulai terdorong untuk mengumpulkan informasi mengenai topik yang akan mereka bahas yang kemudian disajikan melalui tulisan. Peningkatan ketelitian dan keterampilan menulis siswa juga terjadi karena peneliti menggunakan model pembelajaran Problem Based Learning (PBL). Pernyataan peneliti tersebut didukung oleh Shoimin yang mengungkapkan beberapa kelebihan dari pembelajaran Problem Based Learning (PBL) antara lain: siswa didorong untuk memiliki kemampuan memecahkan masalah dalam situasi nyata, memiliki kemampuan membangun pengetahuannya sendiri melalui aktivitas belajar, terbiasa menggunakan sumber-sumber pengetahuan baik dari perpustakaan internet, wawancara, dan observasi, memiliki kemampuan untuk melakukan komunikasi ilmiah dalam kegiatan diskusi, kesulitan belajar siswa secara individu dapat diatasi melalui kerja kelompok dalam bentuk peer teaching [15].

\subsection{Pembahasan}

Berdasarkan hasil penelitian yang telah dilaksanakan di kelas V SDN Cangkringan 1, menunjukkan bahwa pembelajaran bahasa indonesia melalui model pembelajaran Problem Based Learning (PBL) secara daring yaitu dengan memanfaatkan aplikasi whatsapp dan google meet berhasil dapat meningkatkan ketelitian dan keterampilan menulis siswa. Peningkatan ketelitian dan keterampilan menulis disajikan dalam tabel berikut.

\begin{tabular}{cccc}
\multicolumn{4}{c}{ Tabel 5. Capaian Peningkatan Ketelitian dan Keterampilan Menulis Siswa } \\
\hline \multirow{4}{*}{ Ketelitian } & \multicolumn{2}{c}{ Nilai rata-rata } & Jumlah ketuntasan \\
\cline { 2 - 4 } & Pra siklus & 41,1 (kategori kurang teliti) & 0 \\
& Siklus I & 65,6 (kategori Teliti) & 2 \\
& Siklus II & 75,5 (kategori Teliti) & 6 \\
\hline \multirow{3}{*}{ Keterampilan Menulis } & Pra siklus & 59 & 0 \\
& Siklus I & 67,7 & 1 \\
& Siklus II & 76,5 & 6 \\
\hline
\end{tabular}

Berdasarkan tabel di atas, diketahui bahwa ketelitian siswa meningkat dibuktikan dengan nilai rata-rata meningkat dari 41,1 menjadi 65,6 pada siklus I dan pada siklus II mengalami peningkatan kembali menjadi 75,5. Peningkatan juga didapatkan pada variabel keterampilan menulis. Peningkatan keterampilan menulis pada siswa dibuktikan dengan nilai rata-rata pra siklus yaitu 59 meningkat dari 67,7 pada siklus I dan pada siklus II mengalami peningkatan kembali menjadi 76,5.

Peningkatan ketelitian dan keterampilan menulis dipengaruhi oleh temuan masalah dan rancangan perbaikan yang dilakukan. Sebelum dilakukannya tindakan guru belum menerapkan model pembelajaran Problem Based Learning (PBL). Sehingga peneliti menerapkan model Problem Based Learning (PBL) dalam pembelajaran pada siklus I maupun siklus II. Model pembelajaran Problem Based Learning (PBL) adalah merupakan sebuah model pembelajaran yang menyajikan berbagai permasalahan nyata dalam kehidupan seharihari siswa sehingga merangsang siswa untuk belajar. Dalam model pembelajaran Problem Based Learning (PBL) terdapat 5 langkah yaitu: 1) Orientasi peserta didik pada masalah, 2) Mengorganisasi peserta didik untuk belajar, 3) Memandu penyelidikan secara mandiri atau kelompok, 4) Mengembangkan dan menyajikan hasil kerja, 5) Menganalisis dan mengevaluasi proses pemecahan masalah [7].

Berdasarkan hasil observasi dengan menerapkan model pembelajaran Problem Based Learning (PBL) pada siklus I hasil ketelitian dan keterampilan menulis siswa belum optimal atau belum mencapai kriteria indikator keberhasilan yang ditetapkan yaitu pada variabel ketelitian nilai rata-rata belum mencapai $\geq 70$ dengan kategori teliti dan pada variabel keterampilan menulis nilai rata-rata belum mencapai $\geq 70$. Dari siklus I pada variabel ketelitian di dapatkan rata-rata nilai 65,6 dengan rincian dari 9 siswa, sebanyak 2 siswa mendapatkan nilai dengan kriteria tuntas dan 7 siswa belum tuntas, dari 9 siswa sebanyak 7 siswa masuk ke dalam kategori teliti dan 2 siswa cukup teliti. Kesulitan yang dialami siswa yaitu 1) penulisan tanda baca, misalnya tidak menuliskan titik (.) pada akhir kalimat dan tidak memberikan tanda koma (,) pada kalimat-kalimat tertentu. 2) penulisan huruf kapital, misalnya huruf $\mathbf{G}$ pada kata Gunung berapi di awal kalimat ditulis gunung berapi. 3) menuliskan kata, misalnya untuk ditulis untu, naik ditulis naki.

Pada siklus II pada variabel ketelitian nilai rata-rata ketelitian siswa sudah mencapai kriteria keberhasilan yang sudah ditentukan dengan hasil rata-rata nilai 75,5, dengan rincian yaitu dari 9 siswa sebanyak 6 siswa mendapatkan nilai dengan kriteria tuntas dan 3 siswa belum tuntas, dan dari 9 siswa, sebanyak 2 siswa masuk dalam kategori sangat teliti dan 7 siswa teliti. Sedangkan pada variabel keterampilan menulis pada siklus I didapatkan rata-rata nilai 67,7 dengan rincian dari 9 siswa, sebanyak 1 siswa mendapatkan nilai dengan kriteria 
tuntas dan 8 siswa belum tuntas. Kesulitan yang dialami siswa yaitu 1) Penulisan kata belum tepat, misalnya tinggi ditulis tingi, menggunakan ditulis mengunakan, magma ditulis magam, ditimbulkan ditulis di timbulkan, diciptakan ditulis di ciptakan. 2) tidak memberikan judul pada teks yang ditulis. 3) kerapian masih rendah, misalnya oleh suatu benda ditulis olehsuatu benda. 4) Tedapat coretan dan tip-ex pada lembar kerja.

Pada siklus II pada variabel keterampilan menulis nilai rata-rata keterampilan menulis siswa sudah mencapai kriteria indikator keberhasilan yang sudah ditentukan dengan hasil rata-rata nilai 76,5 dengan rincian yaitu dari 9 siswa sebanyak 6 siswa mendapatkan nilai dengan kriteria tuntas dan 3 siswa belum tuntas.

\section{KESIMPULAN}

Upaya peningkatan ketelitian dan keterampilan menulis siswa kelas V SDN Cangkringan 1 pada materi teks eksplanasi dilaksanakan dengan menggunakan model pembelajaran Problem Based Learning (PBL) dengan lima langkah sebagai berikut: orientasi peserta didik pada masalah, mengorganisasi peserta didik untuk belajar, memandu penyelidikan secara mandiri atau kelompok, mengembangkan dan menyajikan hasil kerja, menganalisis dan mengevaluasi proses pemecahan masalah.

Penerapan model pembelajaran Problem Based Learning (PBL) secara daring dapat meningkatkan ketelitian siswa kelas V SDN Cangkringan 1 dalam pembelajaran bahasa indonesia materi teks eksplanasi. Dengan mengalami peningkatan rata-rata nilai sebesar 34,4 dari 41,1 menjadi 75,5 dengan rincian 6 siswa tuntas dan 3 siswa belum tuntas dan kategori ketelitian yang diperoleh dari 9 siswa yaitu 2 siswa masuk ke dalam kategori sangat teliti dan 7 siswa teliti.

Penerapan model pembelajaran Problem Based Learning (PBL) dapat meningkatkan keterampilan menulis siswa kelas V SDN Cangkringan 1 dalam pembelajaran bahasa indonesia materi teks eksplanasi. Peningkatan rata-rata nilai sebesar 17,5 dari 59 menjadi 76,5 dengan rincian 6 siswa tuntas dan 3 siswa belum tuntas.

\section{DAFTAR PUSTAKA}

[1] D. Nurjamal, dkk, Terampil Berbahasa. Bandung: Alfabeta, 2011.

[2] Z. Musaba, Bahasa Indonesia Untuk Mahasiswa. Yogyakarta: CV Aswaja Pressindo, 2012.

[3] R. Imron, Ayo Senang Menulis Karya Tulis Ilmiah. Jakarta: Media Pustaka, 2014.

[4] D Nurjamal, W Sumirat, R Darwis, Terampil Berbahasa. Bandung: Alfabeta, 2011.

[5] E.T Priyatni, Desain Pembelajaran Bahasa Indonesia dalam Kuirikulum 2013. Jakarta: Bumi Aksara, 2014.

[6] Ngalimun, Strategi dan Model Pembelajaran. Yogyakarta: Aswajaya Pessindo, 2012.

[7] S. Kurniasih, Strategi-strategi Pembelajaran. Bandung: Alfabeta, 2014.

[8] A. Shoimin, 68 Model Pembelajaran Inovatif dalam Kurikulum 2013. Yogyakarta: Ar-ruzz Media, 2014.

[9] N. Wedyawati dan Y. Lisa, Pembelajaran IPA di Sekolah Dasar. Yogyakarta: CV Budi Utama, 2018.

[10] A. F. Hidayat, Penelitian Tindakan Kelas. Jakarta: UP, 2013.

[11] S. Arikunto, Prosedur Penelitian Suatu Pendekatan Praktik. Jakarta: Rineka Cipta, 2014.

[12] W. Sanjaya, Penelitian Tindakan Kelas. Jakarta: Kencana, 2011.

[13] F. Hikmawati, Metodologi Penelitian. Depok: PT Rajagrafindo Persada, 2017.

[14] Saukardjo, Kumpulan Materi Evaluasi Pembelajaran. Yogyakarta: UNY, 2018.

[15] A. G. Chrisna, "Penggunaan Kartu Bergambar untuk Meningkatkan Pemahaman, Ketelitian, dan Keterampilan Menulis Deskripsi Siswa Kelas 1 SD", 3 September 2015. [Online]. Tersedia: https://repository.usd.ac.id/722/ [Diakses 10 Februari 2021]. 
